\title{
ELECTRONIC GOVERNMENT AND SOCIAL SATISFACTION: ANALYSIS OF SOCIAL CONDITIONS FOR TIJUANA
}

\author{
Alma Beatriz Navarro Cerda \\ Ph.D. (in Global Development Studies), a full-time professor, \\ Faculty of Economics and International Relations, \\ Autonomous University of Baja California. \\ Address: Calzada Universidad. 14418 Parque Industrial Internacional \\ Tijuana, B.C. México C.P. 22427. \\ E-mail: beatriznavarro@uabc.edu.mx
}

\section{Martin Cutberto Vera Martinez}

Ph.D. (in Government and Public Administration),

a full-time professor, Faculty of Economics and International

Relations, Autonomous University of Baja California.

Address: Calzada Universidad. 14418 Parque Industrial

Internacional Tijuana, B.C. México C.P. 22427

E-mail: martin.vera@uabc.edu.mx

\section{Julio Cesar Lopez Gaeta}

Master (in Public Administration), a full-time professor, Faculty of Social and Political Sciences, Autonomous University of Baja California.

Address: Avenida Monclova s/n Ex Ejido Coahuila C.P. 21360,

Mexicali, Baja California, Mexico

E-mail: jlopez68@uabc.edu.mx

\begin{abstract}
This work explores the social elements that characterize the city of Tijuana, with the purpose of understanding if there is a disposition related to social capacities for the implementation of an electronic government. In the first part, a theoretical and contextual analysis of electronic government is made; afterwards the data obtained for Tijuana is analyzed as a result of a direct investigation in Baja California, with an emphasis on Tijuana. The main finding is whether or not the social conditions exist to make an implementation of an effective electronic government in Tijuana. The mixed methodology used part of Gurr's postulate regarding the link between relative deprivation and social conflict and we hypothesized that it is required to have a medium-high degree of social satisfaction in order to make the implementation of an electronic government.
\end{abstract}

Keywords: electronic government; social satisfaction; state evolution; technologies; technological development.

Citation: Navarro, A., Vera, M. \& Lopez, J. (2018). Electronic Government and Social Satisfaction: Analysis of Social Conditions for Tijuana. Public Administration Issue, Special Issue II (electronic edition), pp. 84-97 (in English); DOI: 10.17323/1999-5431-2018-0-6-84-97 


\section{Making a definition of electronic government}

The theoretical construction of new paradigms is a product of social evolution, which has as its main feature non-linearity, which is why they usually face the challenges of identifying time as a starting point, followed by acceptance for their social creation. In terms of the state functions, the State has been attributed with everything related to the maintenance of the individual's life and that which surrounds it, the elements of nature being the main agents to be controlled, in order to achieve the main object, which is to keep human life safe.

In this way, state functions have been involved in increasingly complex processes associated with both group and individual needs. For classical theorists such as Bonnin and Hobbes, men were born to live in society, not only for the need to stay safe, but for the creation of intrinsic elements to the very existence of his nature that generates links in the moral world.

Derived from this need for permanence and submission to a higher structure, the individual accepts by tradition state control. However, the state evolution has given rise to a construction of governmental structures, which has become increasingly complex throughout the world and involves power relations with actors competing for power either through mechanisms of representativeness or informal ways through influence peddling.

Hence, derived from governmental evolutionary asymmetries, or power relations that involve other actors and supra-state structures, from the end of the 20th century, globalization processes have pushed towards standardization, emerging paradigms and giving life through the new technologies to what we know today as electronic government.

It is through this channel that electronic government has been built, based on technological development, but above all in countries like the United Kingdom, Australia, and the Republic of Korea, it has been the wide awareness of government actors for the search for better practices through the reduction of inefficient governance apparatus towards transformation to a government that optimizes its resources.

In conceptual terms we should establish a link between public administration and electronic government. When we refer to public administration we are inferring about all the aspects in which the State intervenes on the daily life of the individual, in such a way that the very existence of the state organization is subject to the way in which its management model is adapted. While inferring that since electronic government has developed from the exponential growth of technologies giving rise to another major phenomenon that is "cyberspace", which is deliberately associated with globalization, it results in a paradox where the solution to the problems of the distribution of wealth is attributed to globalization, just as it has happened to democracy as a "magic" formula to fix all the political and social problems of liberal governments.

Likewise, high expectations have been placed on electronic government in the literature, where for its conformation it seems that there is a consensus about the possibilities of improvement attributed to it.

At the international level, organizations such as the World Bank (WB), the Organization for Economic Cooperation and Development (OECD), and the 
United Nations (UN) have been the actors in the global arena that are defining the guidelines on which to sustain an electronic government, The UN is the organization whose purpose is to provide tools to solve problems related to the life and survival of the individual. I will start by pointing out that for the UN, through the Ibero-American letter for E-government, the main objectives are to determine the conceptual bases and the components that will constitute it (CLAD, 2007), which is why the World Bank has proposed to support the modernization of the public sector through financing oriented to the acquisition of technologies in terms of technologies that facilitate regional development.

For its part, the OECD has maintained a special interest in the terms of e-government, for example during 2016 they held a round table called "round table on digital governance and business competitiveness" which was hosted by Cancun, Mexico, and that in addition to the contributions regarding the advantages brought about by the use of technologies applied to public services, it is worth noting that at this round table the objective was oriented towards the search for greater competitiveness by linking it with the business sectors, which are the central axis of all governments through private participation. Clearly, what stood out was the case of the United Kingdom with the "Red Tape Challenge" project, as well as the fact that in Mexico the great challenge is the gap in the widespread use of technologies (OECD, 2016).

In retrospect, it is worth remembering that the Inter-American Development Bank, in 2002, published a document called "Practical Guide for e-government: Issues, impacts and perceptions", in which the definition of electronic government proposed by the United Nations is retaken. United through the division of economy and public administration as "a permanent commitment of the government to improve the relationship between citizens and public administration, through the efficient and efficient exchange of services, information and knowledge" (UPAN, 2002). In this document a description of the users, the benefits, the risks, and the regulation among other fundamental elements is made, in order to carry out a better implementation process provided with the necessary conditions for its success. It is the most modern version being the one proposed by the surveys published by the UN E-Government Survey, from 2003 until the most recent in 2018, in which it examined in which way governments have used the E-government and the technologies of the information to build sustainable and resilient societies (Unit Nations, 2018). As well as this is the United Kingdom version, called "ICT Impact Assessment Guidelines", published by the European Commission, (Zamboni et al., 2018) where scope and preparation for information technologies is evaluated in order to provide support in the policies that are designed having been derived from that information.

\section{Contextual elements around electronic government}

For its part, the UN, has linked its efforts to understand the technological capabilities of governments, developing a survey that aims to provide the necessary and sufficient information to assimilate the changes in the governmental sphere regarding the use of information technologies, as well as the 
construction of more aware societies of their acts and those that are reflected in societies that improve their environment and ability to overcome individual critical circumstances.

The needs detected by the UN, as well as to contextualize the general situation of Mexico, resulted in the Ranking of the development index of electronic government, which has had a varied behavior. The following table shows the places that Mexico has occupied, where it can be observed that in the first survey of 2001 it occupied 22nd place and for 2018 it was in 64th place, thus going down 42 places. And being able to be competitive only if it is compared with Central America, where it has managed to reach a better location in the index.

Table 1

\section{Places that Mexico has occupied in the electronic government survey of the UNO}

\begin{tabular}{|c|c|c|}
\hline Year & Ranking & Index \\
\hline 2001 & 22 & 2.16 \\
\hline 2003 & 30 & 0.593 \\
\hline 2004 & 30 & 0.5957 \\
\hline 2005 & 31 & 0.6061 \\
\hline 2008 & 37 & 0.5893 \\
\hline 2010 & 56 & 0.5150 \\
\hline 2012 & 55 & 0.6240 \\
\hline 2014 & 63 & 0.5733 \\
\hline 2016 & 59 & 0.6195 \\
\hline 2018 & 64 & 0.6818 \\
\hline
\end{tabular}

Source: Own elaboration with official data of the UN EGDI.

The methodology used since 2003 in the development index of the electronic government of the United Nations (EGDI) is a composite indicator that measures the willingness and ability of national administrations to use the technologies of information and communications in the provision of public services.

Methodologically, the EGDI is the weighted average of three standardized scores of the most important dimensions of electronic government, these are: scope and quality of online services, the state of development of telecommunications infrastructure and the inherent human capital. In 2001, the quantification of results was based on a numerical scale of 1 to 5 , where one represents an emerging presence and five represents that it is fully integrated, with the best rating.

In the 2012 survey, it was highlighted that Mexico has worked to reduce the digital divide, and in 2011, a full search service was included that indexes the federal, state and municipal portals daily. Likewise, the national portal expanded online services to citizens, including a tool used for anonymously transmitting con- 
cerns and needs to the authorities. It is also mentioned that Mexico is among the select group of the $19 \%$ of countries that offer a single subscription service.

In the previous table from 2008, it can be seen that its fall in the rating obtained in the index begins, although it still has a good place in the ranking of the Electronic Government Development Index, that is why we question whether or not the results of the index will be related to the beginning of a new sexennium in Mexico. As such, it would be necessary to investigate the actions carried out by President Felipe Calderón who represents a political party largely considered conservative and whose actions have had direct impacts in terms of Information and Communication Technologies (TIC'S).

\section{Methodological construction to visualize electronic government in Tijuana}

To date, several models have been developed for the measurement of electronic government. These evaluation models have been designed for e-government cases already implemented. They have, as their main characteristics, the dimensions of the "information" and the "transaction of the services". In the vast majority of these model cases, it is assumed that an electronic government is being evaluated. Basically all of them are developed from the functionality of their web portals, however one would have to question whether the web pages are themselves the electronic government or only comply with transparency because they are informative websites. Below is a diagram regarding the characteristics of the evaluation models (Figure).

Figure

\section{Common elements of evaluation schemes for electronic government}

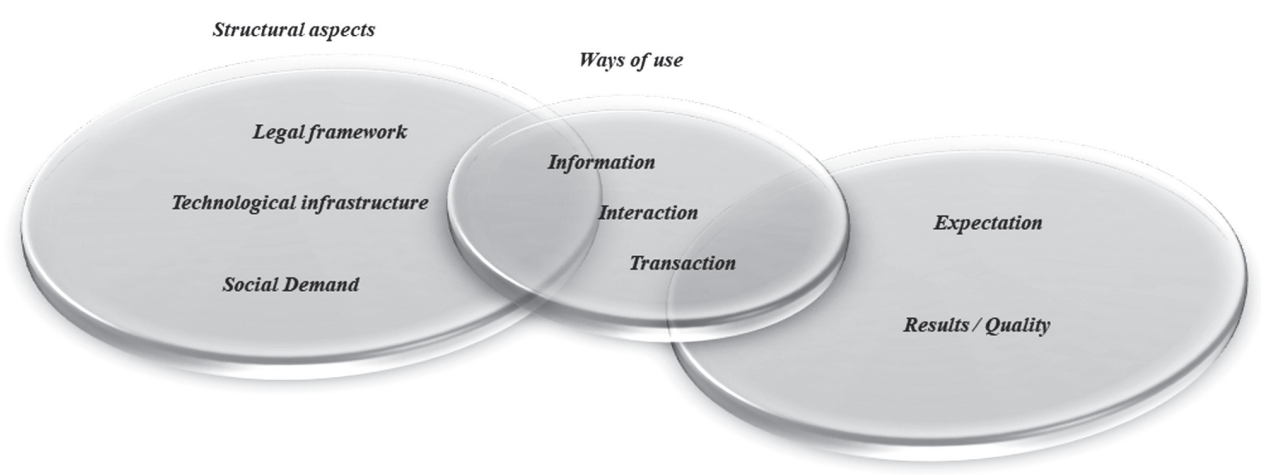

In this sense, the characteristic elements of what is now accepted as electronic government, point to the genesis in the request for services, through the web pages. For what would have to expect if these governmental organizations can be considered subjects of analysis in this subject due to their incipient use of technologies, as well as a limitation in their contribution to satisfy citizens' needs. In this sense, it would be worth wondering if what is being measured is electronic government. Or rather, is it the functionality of the websites of some government institutions that is being measured? 
Another question is derived from Gurr's theory regarding the causes of political violence, which from a psychological point of view suggests that people resort to political violence because they suffer from relative deprivation, defining "relative deprivation" as the lack of income, wealth, position, quality of life and political rights (Sanders, 2010) on which individuals are convinced that they deserve to be supported by the right to self-determination, a product of Western democracies and the rule of law.

Derived from this thesis is the hypothesis that a medium-high degree of social satisfaction in society is required to make the implementation of an electronic government relevant and possible. As a result of these questions and given that this work is the result of an investigation, the instrument designed was a survey to assess the current state of social conditions in Baja California, Tijuana being our subject of study in this work and the disposition of citizens in the use of ICTs and in their undertaking of actions related to online government procedures.

In order to clarify the central ideas it is pertinent to mention that the recent interest in the in-depth study of electronic government, considered as a new social phenomenon and derived from the complexity in the evolution of technologies, by nature has belonged to the disciplinary field of public administration, having public policies as its main support.

Because it seeks to know what the social conditions for the implementation of an electronic government are, the instrument designed had, as subjects of study for its application, the general public and from this the sample was estimated to determine the number of applications of the instrument and collect information in Tijuana. A level of confidence of $99 \%$ was determined, with a margin of error of an estimated 5\%, resulting in the following: according to data from the National Institute of Statistics and Geography (INEGI) of Mexico, in 2017 the population of Baja California was 3,315,766 inhabitants, this being the universe of the sample and through the probabilistic method the number was calculated in the five municipalities of the State, having a population of $1,641,570$ which corresponds to a $49.51 \%$ of the sample size, so 330 surveys were conducted in that municipality.

\section{Social conditions in Tijuana and its predisposition for an electronic government}

From a theoretical perspective, the life of an electronic government is discussed when providing public services every day of the year, 24 hours a day. So there should be a level of social acceptance towards government structures. However, the following considerations should be made in order to understand the type of phenomenon that is being experienced.

First, I briefly explain that Ted Gurr's causal model of civil conflicts measures the level of relative deprivation and the relationship it maintains with the potential for social conflict. The term relative deprivation uses it to denote the discrepancy perceived by the social group or group of individuals, and as a trigger to postulate their response and / or their participation in a social struggle, is determined by the interventions and their social conditions. 
He also states that "the fundamental basis for which conflicts vary is the magnitude that is determined by the intensity in which relative deprivation is supported by these groups", and measured by three social variables, which are the coercive potential, institutionalization and social facilitation (Gurr, 1968). However, Gurr based on the fact that the greater the relative deprivation, the greater the social conflict.

Therefore, we pose as a central question, if in reality there are social conditions to implementing an e-government in Tijuana? If so, it would be required to be satisfied or moderately satisfied in terms of your life so that this is a social reflection and, if possible, face a lower level of resistance in the implementation process, thinking of it as a public policy on a larger scale.

To this end, a relationship is established between the BIARE (self-reported welfare), [a set of indicators called "Subjective Well-Being"], which has been designed by the OECD, and aims to observe beyond the conventional. In general terms, subjective well-being is considered based on a self-assessment carried out by citizens, relative to their level of happiness in their environment. In the following table the eudemonic subjective well-being indicators and the average general satisfaction of the population are exposed.

In which it can be observed that an average of $48.44 \%$ of Mexico's population predominates as moderately satisfied with life, as of January 2018. The data generated by the INEGI of BIARE, still do not contain the survey extended to 2018, so they have taken the 2014 data as the closest reference to the temporal linearity, and with this we made a comparison between the data of the general average of Mexico, with those of Baja California.

Table 2

BIARE from Mexico and Baja California

\begin{tabular}{|c|c|c|c|c|}
\hline $\begin{array}{l}\text { Subjective well-being } \\
\text { of Mexico, BIARE }\end{array}$ & Dissatisfied & $\begin{array}{c}\text { Little } \\
\text { satisfied }\end{array}$ & $\begin{array}{l}\text { Moderately } \\
\text { satisfied }\end{array}$ & Satisfied \\
\hline $\begin{array}{l}\% \text { of Population according } \\
\text { to level of general satisfaction, } \\
\text { data to January } 2018\end{array}$ & 2.15 & 8.56 & 48.44 & 44.00 \\
\hline $\begin{array}{l}\text { Mexico, expanded } \\
\text { survey } 2014^{\star} \text { Eudemonic } \\
\text { statements }\end{array}$ & $\begin{array}{c}\text { Be free } \\
\text { to decide } \\
\text { your own life }\end{array}$ & Feel lucky & $\begin{array}{l}\text { Feeling } \\
\text { good about } \\
\text { yourself }\end{array}$ & $\begin{array}{l}\text { Feeling that things } \\
\text { turn out well or badly } \\
\text { depends on oneself }\end{array}$ \\
\hline Satisfied (10-9) & 76.99 & 72.07 & 62.23 & 69.33 \\
\hline Moderately satisfied (7-8) & 19.32 & 22.80 & 30.76 & 23.55 \\
\hline Little satisfied (5-6) & 2.79 & 3.36 & 5.23 & 5.79 \\
\hline Dissatisfied (0-4) & 0.88 & 1.75 & 1.76 & 1.31 \\
\hline $\begin{array}{l}\text { Baja California expanded } \\
\text { survey } 2014^{\star} \text { Eudemonic } \\
\text { statements }\end{array}$ & $\begin{array}{c}\text { Be free } \\
\text { to decide } \\
\text { your own life }\end{array}$ & Feel lucky & $\begin{array}{l}\text { Feeling } \\
\text { good about } \\
\text { yourself }\end{array}$ & $\begin{array}{l}\text { Feeling that things } \\
\text { turn out well or badly } \\
\text { depends on oneself }\end{array}$ \\
\hline Average & 9.2 & 9.0 & 8.7 & 8.9 \\
\hline
\end{tabular}

Source: Own elaboration with INEGI data, Subjective well-being - BIARE Expanded, survey 2014 and 2018. 
It stands out that Baja obtains an average 9.2 (in a scale of 1 to 100) in terms of the population that it considers to be free to decide its own life. It also gets a very good rating on feeling lucky, feeling good about themselves and the fact that they consider things to be right or wrong is a result of their actions.

\section{Socioeconomic characteristics of Tijuana, Baja California}

From the previous explanation and with the purpose of contextualizing the Tijuana scenario, the main results obtained in our research are exposed. Of the total surveys, $60 \%$ of respondents were the heads of family where $30.80 \%$ were women and $69.19 \%$ were men. Salary difference by gender was $39.29 \%$, and the average age of the respondents was 36 years.

Table 3

\section{Income for gender}

\begin{tabular}{|l|c|c|}
\hline \multicolumn{1}{|c|}{ Gender } & Heads of family & $\begin{array}{c}\text { Average } \\
\text { Monthly income usd }\end{array}$ \\
\hline Female & 30.80 & $\$ 785.03$ \\
\hline Male & 69.19 & $\$ 1,292.95$ \\
\hline Difference & - & $\$ 507.92$ \\
\hline
\end{tabular}

Regarding civil status, $48 \%$ are single, $35 \%$ are married, $4 \%$ are divorced and $13 \%$ are free status union and widowed. 51\% are from Baja California, $10 \%$ from Mexico City, and 8\% from Sinaloa; these are the three states with the highest percentage residing in Baja California. Regarding educational level, $40 \%$ completed a degree at a public college, $18 \%$ public middle school and $17 \%$ public high school.

Since the main purpose of the survey is to understand the predisposition to the e-government online procedures, the starting point was to request information regarding what type of procedure they performed, the time it took for them to complete their procedure and their level of satisfaction with their processing.

\section{The most relevant data were the following:}

For contextual purposes, it is mentioned that the period of application for the survey was during the months of August to November of 2017; $90 \%$ of the citizens of Tijuana managed to complete their process, the other $10 \%$ failed to complete it. The most performed procedures were the following: recordings of no criminal record with $64.5 \%$; after that continuing with is a drastic decrease, with the following services being 9\% respectively; requests for deeds (these are official copies of property titles before registration public); payments (these can be in relation to the aid received, request for check, payment of rights, management, taxes, income from writing, fine, land, property and/or productive project); and finally applications for registrations by mercantile companies by $8.5 \%$. The following table shows the data in percentage terms relevant to the respondents' experience of the process. 
Table 4

\section{Perception of respondents' experience of government processes, $\%$}

\begin{tabular}{|c|c|c|c|c|c|c|c|c|c|c|c|c|c|c|c|c|c|}
\hline \multirow[b]{2}{*}{$\begin{array}{c}\text { Indicator } \\
\text { Unit } \\
\text { of Measurement }\end{array}$} & \multirow[b]{2}{*}{ Yes } & \multirow[b]{2}{*}{ No } & \multicolumn{6}{|c|}{ Average time } & \multicolumn{6}{|c|}{ Satisfaction scale } & \multicolumn{3}{|c|}{ Qualification } \\
\hline & & & $\frac{0}{1}$ & 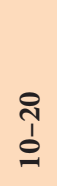 & ê & है & 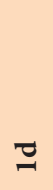 & 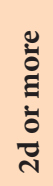 & $\begin{array}{c}1 \\
\text { al } \\
5\end{array}$ & 6 & 7 & 8 & 9 & 10 & है & 苛 & 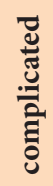 \\
\hline $\begin{array}{l}\text { It was possible } \\
\text { to complete } \\
\text { its process }\end{array}$ & 90 & 10 & & & & & & & & & & & & & & & \\
\hline $\begin{array}{l}\text { How long it took } \\
\text { him to complete } \\
\text { his process }\end{array}$ & & & 34 & 15 & 12 & 14 & 3 & 22 & & & & & & & & & \\
\hline $\begin{array}{l}\text { How satisfied } \\
\text { was the process } \\
\text { completed }\end{array}$ & & & & & & & & & 6 & 2 & 2 & 19 & 20 & 51 & & & \\
\hline $\begin{array}{l}\text { I prefer to carry } \\
\text { out government } \\
\text { procedures } \\
\text { by going } \\
\text { personally } \\
\text { to the offices }\end{array}$ & 55 & 45 & & & & & & & & & & & & & & & \\
\hline $\begin{array}{l}\text { How do you rate } \\
\text { the procedure } \\
\text { performed for } \\
\text { your government } \\
\text { procedure }\end{array}$ & & & & & & & & & & & & & & & 84 & 7 & 9 \\
\hline
\end{tabular}

Source: Own elaboration through direct research.

The table above highlights that of the users surveyed, $90 \%$ managed to complete the process, while $10 \%$ did not complete it. Also, an interesting result is that $55 \%$ of users prefer to complete the process by going personally, which indicates that even if there were the platforms and the ideal conditions to carry out the online process, there is still a very deep-rooted idea in Tijuana's society of carrying out the procedures in person and not taking into account all the facilities of a highly efficient platform.

Another interesting fact is the level of satisfaction, as $51 \%$ of the respondents are satisfied, qualifying their experience with a rating of ten, while only $6 \%$ disapprove of their satisfaction with the process, despite ratings of 8 and 9 , obtained by $19 \%$ and $20 \%$ respectively in terms of the population satisfied. There is also a clear difference between appreciation of the level of difficulty experienced in the process. Later they were asked if they would like the procedure to have been more agile and they suggest that it be improved.

During the period of government in Tijuana2010-2013, the public services that could beinitiated throughitsweb platformand thus thestatus regardingtheelectronic government of the city of Tijuana was the following: a) Payment of the property tax; b) Reprint of voucher for internet payment; c) Payment of traffic tickets and park- 
ing meters; d) Domain transmission simulator; e) Revalidation of permission for commerce; and f) Request for the issuance of a letter of freedom of encumbrance. Evidently this does not imply the existence of an electronic government but it does allow the introduction of new institutional mechanisms to the population (Navarro, 2014).

Returning to our instrument, we asked them if the participants would like to carry out this process through a technological tool and subsequently asked if they had been informed about the possible procedures that can be done online and the number of procedures that they know can be carried out by the Internet. They were also asked if they have internet access at home and told that they would be self-assessed in their abilities to use technological tools. The most relevant data are shown in the following Table 5.

Table 5

Perception of citizens about e-government and its abilities, \%

\begin{tabular}{|c|c|c|c|c|c|c|c|c|c|c|c|c|}
\hline \multirow[b]{2}{*}{$\begin{array}{c}\text { Indicator } \\
\text { Unit } \\
\text { of measurement }\end{array}$} & \multirow[b]{2}{*}{ Yes } & \multirow[b]{2}{*}{ No } & \multicolumn{4}{|c|}{ Knowledge of online government procedures ${ }^{*}$} & \multicolumn{6}{|c|}{ Self-rating } \\
\hline & & & $\begin{array}{c}\text { Does not } \\
\text { know } \\
\text { paperwork }\end{array}$ & $\begin{array}{l}\text { Know } \\
\text { a proce- } \\
\text { dure }\end{array}$ & $\begin{array}{l}\text { Know } \\
\text { two proce- } \\
\text { dures }\end{array}$ & $\begin{array}{c}\text { Know three } \\
\text { or more } \\
\text { procedures }\end{array}$ & $\begin{array}{c}1 \\
\text { to } \\
5\end{array}$ & 6 & 7 & 8 & 9 & 10 \\
\hline $\begin{array}{l}\text { Carry out } \\
\text { government } \\
\text { procedures through } \\
\text { a technology tool }\end{array}$ & 89 & 11 & & & & & & & & & & \\
\hline $\begin{array}{l}\text { Number } \\
\text { of government } \\
\text { procedures that you } \\
\text { know can } \\
\text { be done online }\end{array}$ & & & 35.37 & 18.48 & 17.57 & 18.81 & & & & & & \\
\hline $\begin{array}{l}\text { You have obtained } \\
\text { information } \\
\text { about the possible } \\
\text { procedures that } \\
\text { can be done online }\end{array}$ & 64 & 36 & & & & & & & & & & \\
\hline $\begin{array}{l}\text { Do you prefer } \\
\text { to carry out } \\
\text { government } \\
\text { procedures } \\
\text { by going personally } \\
\text { to the offices? }\end{array}$ & 55 & 45 & & & & & & & & & & \\
\hline $\begin{array}{l}\text { Do you have } \\
\text { Internet access } \\
\text { at home? }\end{array}$ & 86 & 14 & & & & & & & & & & \\
\hline $\begin{array}{l}\text { How would you } \\
\text { qualify your skills } \\
\text { for the use of } \\
\text { technological tools? }\end{array}$ & & & & & & & 11 & 3 & 9 & 22 & 26 & 29 \\
\hline
\end{tabular}

Source: Own elaboration through direct investigation.

* The $9.77 \%$ missing represents respondents who were confused within government facilities and who confused the paperwork. 
This table highlights two results that are also a contradiction, since $89 \%$ of respondents to Tijuana say they prefer to do the procedures through a technological tool and $11 \%$ do not, but when asked if they would prefer to go personally there was a $55 \%$ that affirmed it and only $45 \%$ said they wanted to go to the government offices, therefore it suggests that $34 \%$ are indecisive people or that they do not understand what electronic government implies. Regarding a socioeconomic indicator, it can be said that the city of Tijuana has a great capacity to have access to electronic information services such as the Internet, since $86 \%$ said they own it at home and $29 \%$ claim to be excellent, in terms of their skills in the use of technological tools.

However, another contradiction is that $35.37 \%$ of respondents do not know of any government procedure that can be performed by technological mechanisms, in contrast to the $18.81 \%$ that know three or more. So we would say that only this percentage of the user population surveyed is the most informed regarding technological mechanisms and their relationship with government procedures.

Returning to the theoretical model of Gurr, in relation to the potential for social action that is conditioned to the satisfaction of the population in possession and enjoyment of material goods, and the hypothesis raised in which it is required to have a medium-high degree of social satisfaction so that the implementation of an electronic government is pertinent and possible, which was measured through satisfaction with the process and their desire to go personally to government offices, it can be said that yes, there are the social conditions that allow it, given that $51 \%$ of the population rated their satisfaction with ten in terms of the process carried out in government offices and in the nine to six scale it was a total of $43 \%$ satisfied and only $6 \%$ dissatisfied.

Also, although $55 \%$ prefer to go personally to the offices, there are the $86 \%$ that have access to the Internet, which implies that they also has the technological equipment to do so and raise the level of their quality of life by being connected. Further, 29\% self-rated with a ten in their skills for the use of technological tools and, with a rating of 6 to $9,60 \%$ feel skillful enough to use them.

The previous results correspond to the data issued by the BIARE for Mexico and for Baja California, reporting $44 \%$ as satisfied and $48.44 \%$ moderately satisfied with the general subjective well-being of Mexico as of January 2018, where for Baja California in 2014, 90\% said they feel lucky and $87 \%$ feel good about it.

\section{Consideration}

The main question that arises derived from these results is whether or not the population possesses the technological skills to do procedures or simply to develop their lifestyle. What would be the reasons why the head of government or the candidates at election time not offer better services through these tools?

On the other hand, we should assume that if there is a lack of knowledge on the part of the head of government about the capacities with which the population is self-evaluated, but we cannot say that it does not know the size of the population that has access to the Internet, given that there is an organization 
dedicated to collecting information of all kinds in Mexico (National Institute of Statistics and Geography, INEGI) and thereby infer that this population if they dominate such tools, so that government authorities have the information and decided do not use it to make a better policies. As mentioned above, if there are social conditions to implement effective e-government in Tijuana. However, the main challenge faced by local governments is the "lack of significant aspects of the effectiveness of electronic platforms" due mainly to the lack of interest of the citizens (Revyakin, SA, 2018) at least in the use of technological tools. That is, even with the high esteem of citizens in the use of technologies, they must have an incentive that guides them to use that knowledge to get involved in government matters at least as a user.

Gurr's postulate regarding the relationship between relative deprivation and social conflict, indicates that for there to be conflict the feeling of absence in the enjoyment of services and goods should be present. However, what he observed is that there is a high degree of social satisfaction in the national average of Mexico and also for Baja California, according to BIARE, and in our research, where $51 \%$ said they were satisfied with a rating of ten in relation to its process, the government process for the enjoyment of some of the services and a very high degree of the population has access to the Internet at home, this population also being considered to have a high estimate of their capacities for the use of technological. Although they were not asked in the survey if they were happy in eudemonics terms, nevertheless the fact that a high degree of population have Internet access in their home is an important indicator in assuming the type of conditions that define their quality of life as well as the possibility of them being informed.

Finally we must emphasize, that from an optimal point of view, one of the main occupations on which current governments should be working, under the assumption of working for the common good and assuming that resources are scarce, is to improve technological conditions to provide electronic services 24 hours a day, 365 days a year, and thus be on the path towards efficiency in the use of resources. However, no current political intentions are observed in Mexico in terms of moving back up the development ranking of the electronic government of the UN. 


\section{REFERENCES}

1. Bertucci, G. (2008). United Nations E-Government Survey 2008: From E-Government to Connected Governance. New York: United Nations. Available at: https://publicadministration. un.org/egovkb/portals/egovkb/Documents/un/2008-Survey/unpan028607.pdf (accessed: 24 September, 2018).

2. eGovernment in the United Kingdom (2016). February, Edition 18.0. Available at: https:// joinup.ec.europa.eu/sites/default/files/inline-files/eGovernment\%20Factsheet\%20in\%20 United\%20Kingdom\%20-\%20February\%202016_Edition\%2018_00\%20-\%20v6_00.pdf (accessed: 24 September, 2018).

3. Gobierno Electrónico (2007). Aprobada por la IX, Conferencia Iberoamericana de Ministros de Administración Pública y Reforma del Estado Pucón, Chile, 31 de mayo y 1 de junio de 2007. Available at: http://old.clad.org/documentos/declaraciones/cartagobelec.pdf (accessed: 24 September, 2018).

4. Gurr, T. (1968). A Causal Model of Civil Strife: A Comparative Analysis Using New Indices. American Political Science Review, vol. 62, no 4, pp. 1104-1124. Available at: http://www. jstor.org/stable/1953907?seq=1\#page_scan_tab_contents (accessed: 24 September, 2018).

5. Navarro, B. \& Moctezuma, P. (2014). La nueva burocracia global electrónica. La problemática de la implementación del gobierno electrónico en Tijuana. Revista iapem, no 89, pp. 167-186. Available at: http://iapem.mx/Revistas/Revista\%2089.pdf (accessed: 24 September, 2018).

6. Hafeez, S. \& Sher, S.W. (Eds). (2006). UN Global E-government Readiness Report 2005: From E-government to E-inclusion. United Nations Publications. New York: United Nations. Available at: https://publicadministration.un.org/egovkb/Portals/egovkb/Documents/un/2005Survey/Complete-survey.pdf (accessed: 24 September, 2018).

7. Revyakin, S.A. (2018). Ob effektivnosti elektronnykh platform uchastiya grazhdan v gosudarstvennom upravlenii [On the Effectiveness of Electronic Platforms of Citizen Participation in Public Administration]. Public Administration Issue, no 2, pp. 94-113. Available at: https://vgmu.hse.ru/data/2018/07/04/1152927525/\%D0\%A0\%D0\%B5\%D0\%B2\%D1\%8F\% D0\%BA\%D0\%B8\%D0\%BD\%202-2018.pdf (accessed: 24 September, 2018).

8. Sanders, D. (2010). Behavioural Analysis. In: David Marsh and Gerry Stoker Theory and Methods in Political Science, 3rd Ed. Palgrave Macmillan.

9. OCDE, (2016). Mesa Redonda sobre Gobierno Digital y Competitividad Empresarial. Organización para la Cooperación y el Desarrollo Económico. Available at: http://www.oecd.org/ internet/mesa-redonda-sobre-gobierno-digital-y-competitividad-empresarial-cancun2016.html (accessed: 24 September, 2018).

10. United Nations. Department of Economic (2010). United Nations E-government Survey 2010: Leveraging E-government at a Time of Financial and Economic Crisis. Vol. 2. United Nations Publications. Available at: https://publicadministration.un.org/egovkb/Portals/egovkb/ Documents/un/2010-Survey/Complete-survey.pdf (accessed: 24 September, 2018).

11. United Nations (2012). United Nations E-Government Survey 2012: E-Government for the People. New York: United Nations. Available at: https://publicadministration.un.org/ egovkb/Portals/egovkb/Documents/un/2012-Survey/Complete-Survey.pdf (accessed: 24 September, 2018). 
12. United Nations (2014). United Nations E-Government Survey 2014: E-Government for the Future We Want. New York: United Nations. Available at: https://publicadministration.un.org/ egovkb/portals/egovkb/documents/un/2014-survey/e-gov_complete_survey-2014.pdf (accessed: 24 September, 2018).

13. United Nations (2017). United Nations E-Government Survey 2016. E-Government in Support of Sustainable Development United Nations. Available at: http://workspace.unpan.org/sites/ Internet/Documents/UNPAN97453.pdf (accessed: 24 September, 2018).

14. United Nations (2018). United Nations E-Government Survey 2018. E-Government in Support of Sustainable Development United Nations. Available at: https://publicadministration. un.org/egovkb/Portals/egovkb/Documents/un/2018-Survey/E-Government\%20Survey\%20 2018_FINAL\%20for\%20web.pdf (accessed: 24 September, 2018).

15. UPAN (2002). Dinsdale Geoff, Chhabra Samir, Rath-Wilson John. Guía Práctica para el Gobierno Electrónico: Cuestiones, Impactos y Percepciones. Banco Interamericano para el Desarrollo. Available at: https://publications.iadb.org/bitstream/handle/11319/5878/gu\%c3\%ada\%20 práctica \%20para\%20el\%20gobierno\%20electrónico\%3a\%20cuestiones\%2c\%20impactos\% 20y\%20percepciones.pdf?sequence=1 (accessed: 13 March, 2018).

16. Tallinn Declaration on Egovernment at the Ministerial Meeting during Estonian Presidency of the Council of the EU on 6 October 2017. Available at: https://ec.europa.eu/digital-singlemarket/en/news/ministerial-declaration-egovernment-tallinn-declaration (accessed: 13 March, 2018).

17. Zamboni, A., Di Giacomo, D. \& Georgiev, F. (2018). ICT Impact Assessment Guidelines. Practical Tools and Guidelines for Assessing ICT Implications. European Union. Available at: https://ec.europa.eu/isa2/sites/isa/files/ict_impact_assessment_guidelines.pdf (accessed: 13 March, 2018). 